\title{
INFORMATION SYSTEM FOR SUPPORT IN BASKETBALL GAME AND PLAYER ANALYSIS
}

\section{INFORMACIJSKI SUSTAV POTPORE U ANALIZI KOŠARKAŠKE UTAK- MICE I IGRAČA}

\author{
Krešimir Lacković ${ }^{1}$, Tomislav Horvat ${ }^{2}$, Ladislav Havaš ${ }^{2}$ \\ Glas Slavonije, Osijek, Croatia ${ }^{1}$; Department of Electrical Engineering, University North, Varaždin, Croatia ${ }^{2}$ \\ Glas Slavonije, Osijek, Hrvatska'; Odjel za elektrotehniku, Sveučilište Sjever, Varaždin, Hrvatska
}

\section{Abstract}

The development and usage of ICT technologies is increasing every day. Nowadays, ICT technologies are being used in almost every industry and lately, especially rapidly in sports. Information related to sport events and sport participants are recorded in a database, which thus enables computer analysis. This paper presents information system Basketball Coach Assistant. The paper presents current version of information system and describes the possibilities of the information system, starting with the architecture up to the individual parts of the information system. The paper also explains a display of a custom menu and user-defined player efficiency index.

\section{Introduction}

The usage of statistical analysis has become an integral part of almost every branch of industry, it is used for entertainment and information purposes and it is used since the earliest beginnings of humanity. Statistical analysis and analysis of the results simplify business decisions and lead to useful and sometimes unexpected information and also to links between data $/ \mathbf{1} /$. When we talk about drawing useful information and discovering unexpected links between data from computer databases, we talk about data mining. The basis for successful data mining analysis is a well-designed database or data warehouses with enough relevant data. Various statistical analysis aspects found its contribution in the sport and became interesting to coaches, sports workers, but also to the fans. Popularly known "figures" have
Sažetak

Razvoj i upotreba ICT tehnologija svakim danom sve je veća. ICT tehnologija koristi se u gotovo svim granama industrije, a u zadnje vrijeme posebno brzo razvija se $u$ sportu. Informacije vezane uz sportske događaje i sportske aktere zapisuju se $\mathrm{u}$ baze podataka te samim time omogućuju i računalnu obradu. U ovom radu bit će prikazan informacijski sustav Basketball Coach Assistant. Rad će prikazati trenutnu verziju informacijskog sustava te opisati mogućnosti samog sustava, počevši od same arhitekture sustava pa sve do pojedinih dijelova sustava. Bit će objašnjen način prikaza prilagođenog izbornika, ali i korisnički definiranog indeksa korisnosti igrača.

become one of the main performance indicator of player or team efficiency. Mathematical evaluation of the player or team efficiency is notational analysis, which will be explained in more detail in later chapters. This paper will present information system Basketball Coach Assistant (BCA), which combines all the functionalities listed in this section. Design of information system Basketball Coach Assistant started with the need of a programmer, who was also the assistant coach of the senior basketball team, for the automatic processing of basketball game statistics and computer-aided discovering of optimal parameters in the training process, but also the game itself. The first version of the information system was called Assistant Coach and was presented at the International Congress on Sport Sciences Research and Technology Support in Lisbon /2/. Initially, the goal was to create an application that will allow user to input game statistics and a possibility to 
print statistical data, notes about their own team and players, and also opponent team and players. The best solutions for technologies have proven to be Web technologies, due to the reason that the game statistics had to be shared between more dislocated coaches, the club management and players. In consultation with the head coach (expert) the initial application requirements were defined (a list of their own players, a list of games, game statistics entry, statistical analysis of the game). The design of the initial requirements started by creating a conceptual model /3/ that was later turned into a relational model. Over time, the requirements for the application have become more complex. New requirements were determined by programmer itself, but also by other club members which led to the frequent changes of conceptual and also the relational model. Moreover, there was a need for the use of the application on mobile devices. The initial idea was to develop a mobile version of a Web application with elements of the expert system which by itself suggests the improvement of some used parameters. For the development of such application as the best solution proved to be, every day more and more popular, responsive design techniques. Responsive web design is an approach to web design aimed at allowing desktop web pages to be viewed in response to the size of the device one is viewing with. The next chapter gives a short overview of the currently available information systems related to the analysis of a basketball game. Remaining chapters of the paper will primarily study the functionality of the information system, starting with the architecture of the system, later describing the user interface, then designing of the custom user menu and at the end about motivation and methods for defining user-defined player efficiency index.

\section{Short review of current available basketball information systems}

The number of information systems developed for use in sport, thus the competition, is growing every day $/ 4 /$. Before moving to the heart of the problem of this paper, currently available information systems that are used for the analysis of a basketball game, but also the player and team efficiency, will be briefly presented. When we talk about the currently available information systems in basketball, in European basketball the standard is an application called FIBA Live Stats. FIBA Live
Stats is a free desktop application that allows live tracking of basketball game in accordance with FIBA standards. The application offers the user a link that enables textual tracking of the basketball game to Internet audience. The main problem of FIBA Live Stats application is that the database is formed on the basis of one game and the analysis of more games is not possible. Regardless of the disadvantages, the basic idea of the tool is obtained, which is tracking the games live. The next software used to analyze the players as individuals, but also the team as a whole is Kroosover. The software offers advanced basketball statistics from the video. Video materials are divided into marked clips from which the important moments are drawn. Unlike FIBA Live Stats, Kroosover is not free. The main strength of Kroosover is video support that allows coaches linking the statistics of players and specific video clips on the field. In addition, Kroosover offers basic game statistics. As can be seen, the above information systems serve the purposes which are predicted, but there is no software that will allow analysis of the game according to coach's desires and thus help in making decisions.

\section{Information System Basketball Coach Assis- tant}

Information System Basketball Coach Assistant (later BCA) is a Web application built using open-source software. The whole application has been developed on today free Web standards (PHP + MySQL), supported with JavaScript and jQuery. Database has been designed and implemented in MySQL relation database /5/, while the programming is performed in script programming language PHP /6/. Access to the information system can only be via a dedicated website. For the purposes of designing analyzed BCA information system the prototype model is used $/ 7 /$. The prototype model has enabled just what was needed to accomplish the project. The prototype model has enabled many user (testers) involvements in the early stages of the development, which served the purpose of early identifying the possible problems so the quality of the product could be set to the highest level. User requirements (one of the application user was also the author of the system) were clearly defined and the need for modificarions was minimal. The biggest changes were made on the quality of design, and that is exactly what the prototype model allows. 
Verification of the system was performed by the author and all involved users involved in the project.

Information System BCA consists of a Website and Web application. The Website contains basic information about the club and its content is defined by the administrator. Content of the Website is shown to external Website users. The Web application offers users a variety of analyses. BCA information system offers total flexibility, in other words, offers a definition of "focus (observed) team". User defines focus team that represents the team whose analysis and notes are displayed within the Web application. In addition, the Web application offers user the possibility to define the time period of analysis. Information system works on client - server architecture. The client sends a query to a server that passively expects requests, accepts the requests, processes it, and sends response back to the client. Because of its responsive design, the client can use a variety of devices, screen sizes, and different types of devices that have a connection to the Internet. The architecture of communication between client and server is given in Figure 1.

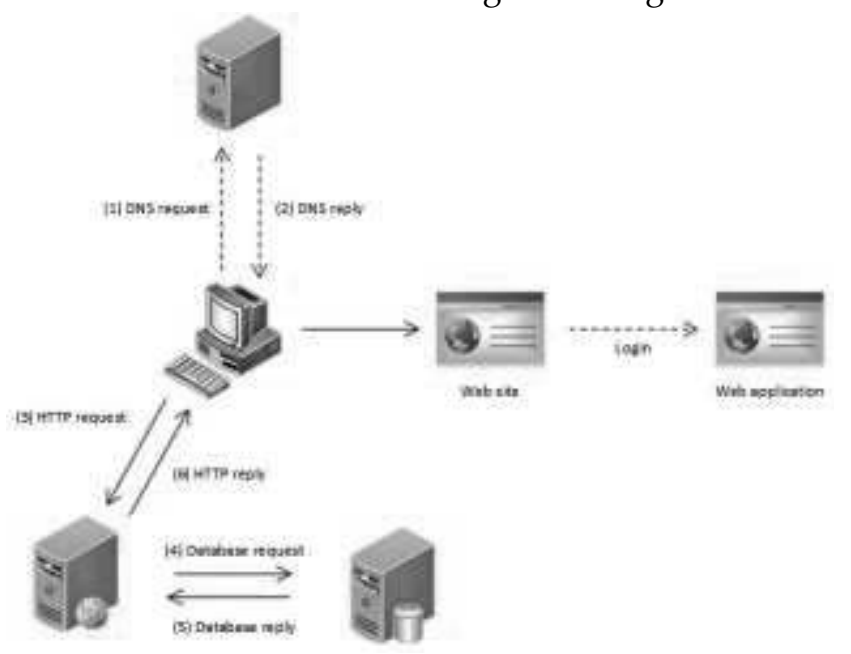

Figure 1. The architecture of BCA information system /2/

For the purpose of information system security, the control mechanism and mechanism against unauthorized access were built. Website that communicates with the application can be accessed by anyone, but the application can be accessed only by authorized users. Web application BCA allows four types of users:

- administrator - has full control of the application (delete, data entry and update), intended for developers and database administrators

- moderator - can enter and delete individual data, intended for the coach and team management

- insider - can see all the data, but cannot modify or delete data, provided for the players and other members of the basketball team

- guest - can see only some parts of the application, designed for a players and the wider audience

Compared to the original version $/ 2 /$, new functionalities were added. The list of new fea- tures is given in chapter four. As already stated, the information system BCA consists of the Website and Web application. Content of the web site is chosen by the administrator on the basis of the interests of the club. Web application consists of several views. User types insider and guest have predefined rights, while the rights of the moderator are specified by the administrator. The administrator assigns moderators their rights, which can lead to point that the moderator has administrator rights or that certain moderator has less rights than guest.

\section{User interface of information system BCA}

\subsection{User interface functionality description}

Main menu of Web application consists of a list of views. Compared to the first version shown in $/ 2 /$, several views were added.

Newly added views are "Coaches", "Advanced Statistics", "Youth" and "News". The view "Fan Area" is expelled in relation to the 
original version. The view "Home" is shown in Figure 1. View "Home", which was also in the previous version, allows user to define "focus" team and time period. In this view, the administrator can also add new users and define their rights.

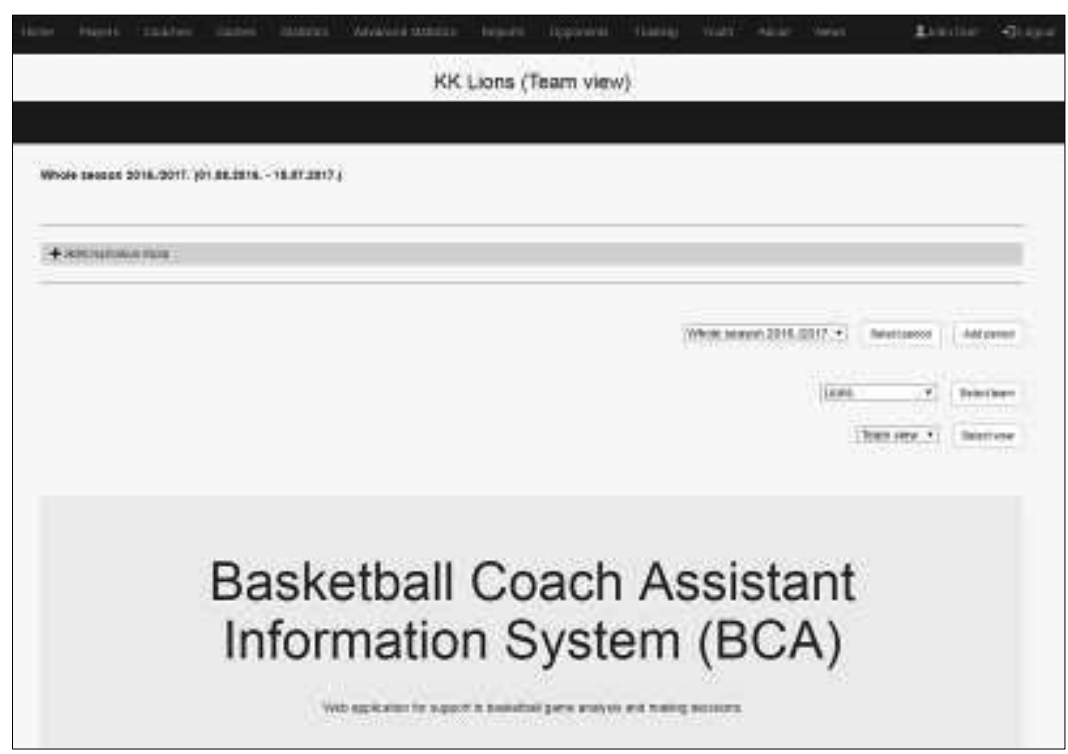

Figure 2. View "Home"

The view "Coaches" offers a list of all coaches and the basic information related to each coach. The view "Advanced Statistics" offers a view of average individual achievements of each player. Compared to the standard statistics displayed in the view "Statistics", the view "Advanced Statistics" allows user additional parameters which describe the contribution of players in the game. Standard statistics is aggregated advanced statistics in which the individual parameters of basic statistics are divided into a few parameters of advanced statistics. The view "Youth" allows user to enter and conduct training and games of all club younger age categories. This view aggregates all the functionality of all other views related to senior team. The view "News" allows the administrator or moderator with the rights of publication possibility to publish news on a Website.

Table 1 shows all application views and subviews. As previously stated, the views and the subviews of the Web page are defined by the administrator of the information system and can vary from user to user.

Table 1. Web application views

\begin{tabular}{|l|l|l|l|}
\hline View & View description & Subview & Subview description \\
\hline Home & $\begin{array}{l}\text { User can define approach } \\
\text { (team or coach), time } \\
\text { period and focus team or } \\
\text { focus coach }\end{array}$ & - & - \\
\hline \multirow{2}{*}{ Players } & Player information. & Player development & $\begin{array}{l}\text { Technical and physical player } \\
\text { development }\end{array}$ \\
\cline { 3 - 5 } & & Players list & $\begin{array}{l}\text { List of all active and inactive play- } \\
\text { ers }\end{array}$ \\
\hline Coaches & List of all coaches. & - & - \\
\hline
\end{tabular}




\begin{tabular}{|c|c|c|c|}
\hline \multirow{3}{*}{ Statistics } & \multirow{3}{*}{$\begin{array}{l}\text { Display of various statis- } \\
\text { tics related to focus team } \\
\text { or focus team players. }\end{array}$} & $\begin{array}{l}\text { Player individual statis- } \\
\text { tics }\end{array}$ & $\begin{array}{l}\text { Individual average statistics of all } \\
\text { focus team senior players. }\end{array}$ \\
\hline & & Team statistics & $\begin{array}{l}\text { Average team statistics of focus } \\
\text { senior team. }\end{array}$ \\
\hline & & Statistics by line-ups & $\begin{array}{l}\text { Statistics by line-ups of focus sen- } \\
\text { ior team. }\end{array}$ \\
\hline Advanced statistics & $\begin{array}{l}\text { Advanced average indi- } \\
\text { vidual focus team players } \\
\text { statistics }\end{array}$ & - & - \\
\hline Reports & $\begin{array}{l}\text { Focus team players re- } \\
\text { port. }\end{array}$ & - & - \\
\hline Opponents & $\begin{array}{l}\text { Notes related to opponent } \\
\text { team or opponent players. }\end{array}$ & - & - \\
\hline Training & $\begin{array}{l}\text { Training of the focus } \\
\text { senior team }\end{array}$ & - & - \\
\hline Youth & $\begin{array}{l}\text { Keeping records of all } \\
\text { young focus team selec- } \\
\text { tions. }\end{array}$ & $\begin{array}{l}\text { Depends on number of } \\
\text { young focus team selec- } \\
\text { tions. }\end{array}$ & $\begin{array}{l}\text { All the functionality of young } \\
\text { team selection related to senior } \\
\text { team. }\end{array}$ \\
\hline About & $\begin{array}{l}\text { List of focus team man- } \\
\text { agement. }\end{array}$ & - & - \\
\hline News & $\begin{array}{l}\text { User can input news } \\
\text { which will be displayed } \\
\text { on web site. }\end{array}$ & - & - \\
\hline
\end{tabular}

Flowchart of the information system is shown in Figure 2 and shows the main features of the information system. Flowchart part that defines the data entry refers to the input of all data related to any team or player. In particular, it discusses entry of players or teams, entering notes about players or teams and entering games with statistics. User can also enter training plan of "focus" team. Since the system offers complete flexibility, the information system user can be set up in the focus of any team and get all the analysis about any team. 


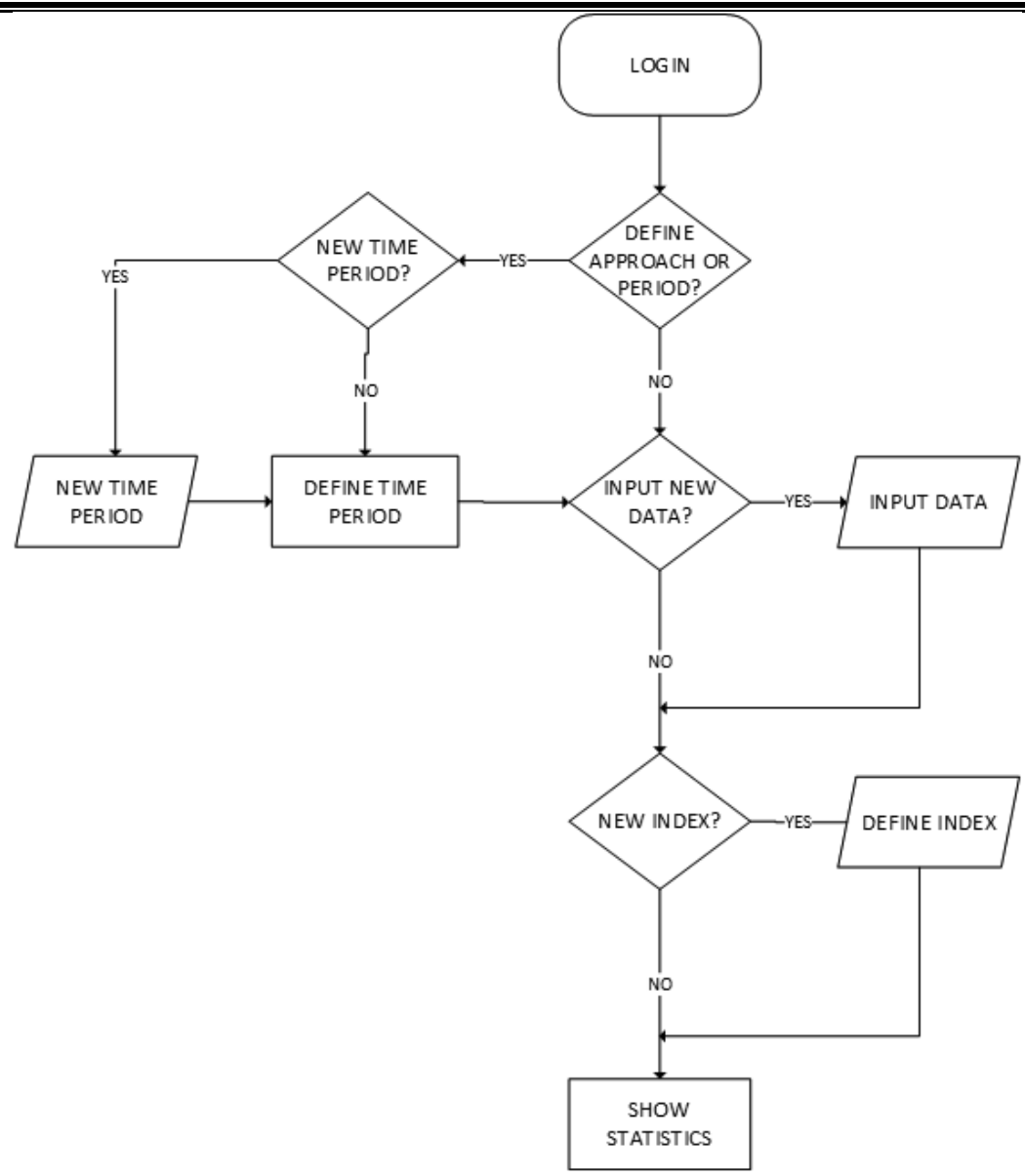

Figure 3. Flowchart of information system BCA

\subsection{Custom menu}

In addition to the classic menu, so-called main menu or navigation which is explained in section 2.1., information system offers the user a custom menu. Actions of each user are recorded in a database and by database analysis, user gets adjusted custom menu. The custom menu shows the most common actions that user used. The content of the custom menu is determined by statistics, the most frequently selected views / subviews are shown to the user.

As previously stated, user actions are entered in a database as log records recording which view / subviews user was selecting. The special care is taken regarding the fact that a record of the repeating actions is not being written into the database, into the database are written actions that are performed after some other action or the next user enters the application. User login and user actions in the information system are recorded in a special relation table that contains all information related to the user account. In the case of reducing user rights, information system takes that into account and to user is not shown view or subview that statistically does not belong to the custom menu.

\section{User defined player efficiency index}

The notation analysis in sport has become a very important part of performance evaluation of player and team. Definition of notation analysis indicates that the notational analysis is collecting and analyzing data collected by observing team or player in a competitive situation /8/, /9/. The basic idea of notational analysis is to identify important parameters and mathematically determinate contribution of each parameter /10/. Mathematical contribution of a parameter is determinated based on the experience of the analyst, expert or the expert system itself. Nowadays there are various player efficiency indexes $/ \mathbf{1 1} /, / \mathbf{7} /$, but this section will show the way user can define their own player efficiency index and thus to evaluate the impact of player or team. Information system gives user possibility to choose which parameters are inter- 
esting and to determine contribution of each parameter. Philosophy views of game differ from coach to coach and as a consequence, different coaches' individual parameters of the game measure in a different way. User-defined player efficiency indexes offer a coach the possibility of separation certain segments in the game, and the contribution of players in a particular game. Therefore, let's say a coach can create a separate efficiency index that refers to offensive part of the game, but also a special efficiency index that applies only on the defensive part of the game. Userdefined indexes showed its usefulness primarily in the analysis of offensive and defensive performance of an individual player where has been noted that offensive-oriented players give very small contribution in the defense area, and that, looking at statistics, defensive part of the player efficiency index is a negligible part of player efficiency index. The information system provides the user with standard basketball games parameters that the user based on his own experience adds, subtracts, multiplies or divides. The user gets default shortcuts of each game parameter and the task of user is to write a mathematical formula that will later be used as a user-defined player efficiency index. Standard player efficiency indexes, such as NBA and PIR /12/, provide a realistic picture of the player or team efficiency, but sometimes it is not enough for basketball coaches or various analysts. User-defined efficiency indexes provide deeper and more accurate analysis of the game.

\section{Conclusion}

The notation analysis in sports has become a very important part, thus the development of information systems that support a coach in making decisions. Information System BCA offers the coach a variety of players and games analysis and helps the coach in making decisions, but also makes correction of some game parameters with the consent of the coach. The system also offers user a prediction of game result based on past results and planned achievements of the team in upcoming games. The prediction game algorithm is shown in $\mathbf{2} /$. Custom menu and user-defined player efficiency indexes proved to be very useful tools in analyzing the player and team efficiency, but also in the speed of access to the requested information. This paper presents the current version of the information system BCA. In the future it is planned to get the system closer to the work in real time which means that the coaches will be able to obtain some useful information during a game or training. Because of the growing amount of data in relational database and data warehouse, the information obtained from the information system will be more precise, as well as the parameters to evaluate player or team efficiency.

Notes

/1/ L. Havaš; Z. Skočir; V. Medved (2013), Modeling of the athlete's training decision support, Technical Gazette

/2/ T. Horvat; L. Havaš; V. Medved (2015), Web Ap plication for Support in Basketball Game Analysis, icSports, Lisbon

/3/ P. Chen (1976), The Entity-Relationship Model Toward a Unified View of Data, ACM Transactions and Database Systems, Vol. 1., No. 1 pp 9-36.

/4/ L.Havaš ; Z. Skočir; V. Medved, (2013), Modeling of the athlete's training decision support, Technical Gazette

/5/ MySQL. Retrieved on September 252016 from https://www.mysql.com/.

/6/ PHP. Retrieved on September 252016 from http://php.net/.

/7/ Z. Lacković (2008), Inženjerski menadžment, Josip Juraj Strossmayer University of Osijek, Faculty of Electrical Engineering, Computer Science and Information Technology Osijek

/8/ M. D. Hughes; I.M Franks (1997), Notational Analysis of Sport". London, E. \&F.N. Spon

19/ M. Hughes; I.M. Franks (2004), Notational Analysis of Sport Systems for better coaching and performance in sport, London, Routledge

/10/ A. Karapidis; A. Fotinakis; K. Taxildaris; J. Fatouros (2001), Factors characterizing a successful performance in basketball, J Hum Mov Stu

/11/ R. Hoofler; J. Payne (1997), Measuring efficiency in the national basket association, Econlett

/12/ Efficiency (basketball). Retrieved on April 102017 from https://en.wikipedia.org/wiki/Efficiency_(basketball ) 